\title{
POLITIK HUKUM PENGAWASAN HAKIM KONSTITUSI
}

\author{
Legal Politics Constitutional Court Control
}

\author{
Muhtadi \\ Fakultas Hukum, Universitas Lampung \\ email: muhtadi.1977@gmail.com
}

\begin{abstract}
In order to preserve and uphold the honor, dignity, and the behavior of the judge is required to supervise the attitude constitutional judge to fit the code of ethics, so that each judge's ruling will be implemented in order to enforce the law and justice based on Pancasila and the Constitution 1945 as a permanent legal political for supervision of the constitutional judges. Whereas legal politics incidental that becomes choice among others: a) Behavior of Constitutional Judges are overseen by the Board of Ethics established by the Constitutional Court, and for the reported judges or suspected violations of ethic codes of Constitutional Judges formed by Honorary Council of the Constitutional Judges whose creation was proposed by Ethics Council, with the task of implementing and serves as ethic judicial; and b) there is no judicial supervision against Constitutional Court's decision as well as supervision of a court decision which was in the Supreme Court through the mechanism of legal remedies (ordinary and extraordinary).
\end{abstract}

Keywords: Supervision, Behavior, Constitutional Judges

\section{abstrak}

Dalam rangka menjaga dan menegakkan kehormatan, keluhuran martabat, serta perilaku hakim diperlukan pengawasan terhadap perilaku hakim konstitusi agar sesuai kode etik dan pedoman perilaku sehingga setiap putusan hakim dilaksanakan dalam rangka menegakkan hukum dan keadilan berdasarkan Pancasila dan UUD Tahun 1945 sebagai politik hukum permanen pengawasan hakim konstitusi. Sedangkan politik hukum insidentil yang menjadi pilihan adalah; a) perilaku hakim Konstitusi diawasi oleh Dewan Etik yang dibentuk MK, sedangkan terhadap hakim terlapor atau terduga melakukan pelanggaran kode etika dan/atau pedoman perilaku hakim Konstitusi dibentuk Majelis Kehormatan Hakim Konstitusi yang pembentukannya diusulkan Dewan Etik, dengan tugas melaksanakan dan berfungsi sebagai peradilan etik; dan b) putusan MK tidak dapat dilakukan pengawasan judisial sebagaimana halnya pengawasan putusan pengadilan yang berada di lingkungan MA melalui mekanisme upaya hukum (biasa dan 
luar biasa). Namun demikian, putusan MK dapat diawasi masyarakat melalui monitoring terhadap pelaksanaan putusan dimaksud, termasuk koreksi melalui kegiatan akademik tetapi tidak dapat merubah putusan.

Kata kunci : pengawasan, perilaku, hakim konstitusi

\section{A. Pendahuluan}

Politik hukum dan kekuasaan berkait erat, saling berkelindan, dan tidak dapat dipisahukuman satu dengan lainnya. Politik sebagai titik awal menuju kekuasaan, dan hukum sebagai instrumen mempertahankan kekuasaan. Tipikal produk politik baik undang-undang ataupun instrumen politik lainnya memunyai karakteristik sebagaimana konfigurasi politik yang berkembang dan menguasai lembaga politik. Undang-undang sebagai sumber legalistik yang berfungsi bingkai bagi penguasa mempertahankan kekuasaan merupakan ciri produk politik otoritarian, represif dan tidak berpihak pada kepentingan masyarakat, kontekstualisasi produk demikian menjadi pembenar dalil Lord Acton bahwa power tens to corrup, and absoute power corrupt absolutely.

Mahfud $\mathrm{MD}^{1}$ mengartikan politik hukum sebagai proses pembuatan dan pelaksanaan hukum yang dapat menunjukkan sifat dan ke arah mana hukum akan dibangun dan ditegakkan. Unsur-unsur politik hukum dimaksud meliputi; 1) pembangunan hukum yang berintikan pembuatan dan pembaharuan terhadap materi-materi hukum agar dapat sesuai dengan kebutuhan; dan 2) pelaksanaan ketentuan hukum yang telah ada termasuk penegasan fungsi lembaga dan pembinaan para penegak hukum.

Satjipto Rahardjo ${ }^{2}$ mengartikan politik hukum sebagai aktivitas memilih dan cara yang hendak dipakai untuk mencapai tujuan sosial dan hukum tertentu dalam masyarakat. Sedangkan Sunaryati Hartono sebagaimana dikutip Armen $\mathrm{Yasir}^{3}$ mendefinisikannya sebagai sebuah alat atau sarana atau langkah yang dapat digunakan oleh pemerintah untuk menciptakan sistem hukum nasional yang dikehendaki dan dengan sistem hukum nasional itu akan diwujudkan cita-cita bangsa Indonesia.

Kajian politik hukum dalam pendekatan Hukum Tata Negara mencakup 1) hal yang substansi dari dalam bidang studi ilmu dan teknik perundang-undangan; 2) menekankan kepada proses politik dan hukum pembentukan produk-produk hukum dan berkaitan dengan badan-badan kenegaraan serta cara kerjanya menetapkan politik hukum dan aturan

\footnotetext{
${ }^{1}$ Mahfud MD, Politik Hukum di Indonesia, (Jakarata: LP3ES, 1998), hlm. 9.

${ }^{2}$ Satjipto Rahardjo, Imu Hukum, (Bandung: Alumni, 1986), hlm. 334.

3 Armen Yasir, Hukum Perundang-undangan, (Bandar Lampung: Justice Publisher, 2014), hlm. 125.
} 
hukum; dan 3) mencakup penyelenggara dan tujuan negara. Iman Syaukani dan A. Ahsin Thohari ${ }^{4}$ menyebutkan bahwa kajian politik hukum mencakup:

1. proses penggalian nilai-nilai dan aspirasi yang berkembang dalam masyarakat oleh penyelenggara negara yang berwenang merumuskan politik hukum;

2. proses perdebatan dan perumusan nilai-nilai dan aspirasi ke dalam rancangan undang-undang oleh penyelenggara yang berwenang;

3. penyelenggara negara yang berwenang merumuskan dan menetapkan poltik hukum;

4. peraturan perundang-undangan yang memuat politik hukum;

5. faktor-faktor yang memengaruhi politik hukum; dan

6. pelaksanaan dari peraturan perundang-undangan yang merupakan implementasi politik hukum.

Persoalan keterkaitan hukum dan politik dalam pendekatan politik hukum menimbulkan beberapa asumsi, antara lain sebagaimana pandangan yang dikemukakan Phillip Nonet dan Philip Schelnik yang kemudian diartikulasikan dalam konteks keindonesiaan oleh Mahfud MD. Keterkaitan demikian menurut Mahfud adalah:

Petama, hukum determinan atas politik dalam arti bahwa kegiatankegiatan politik diatur oleh dan harus tunduk pada aturan hukum; kedua, politik determinan hukum karena hukum merupakan hasil atau kristalisasi dari kehendak-kehendak politik yang saling berinteraksi dan saling bersaingan; dan ketiga, politik dan hukum sebagai subsistem kemasyarakatan berada pada posisi yang sederajat determinasinya seimbang antara yang satu dengan yang lainnya ketika politik sudah jadi produk hukum maka kegiatan politik sudah harus tunduk pada aturan-aturan hukum.

Adapun tujuan politik hukum adalah; 1) sebagai alat yang dipergunakan pemerintah untuk menciptakan suatu sistem hukum nasional yang dikehendaki; 2) sistem hukum nasional itu akan diwujudkan cita-cita bangsa yang lebih besar; dan 3) hukum nasional adalah hukum yang berlandaskan ideologi dan konstitusional negara, Pancasila dan UUD Tahun 1945 .

Bagir Manan ${ }^{5}$ berpendapat bahwa paling tidak terdapat dua lingkup utama politik hukum, yaitu :

1. politik pembentukan hukum; dan

2. politik penegakan hukum.

Politik pembentukan hukum merupakan kebijakan yang bersangkutan dengan penciptaan, pembaharuan dan pengembangan hukum. Mencakup; (a) kebijakan (Pembentukan) peraturan perundang-undangan; (b) kebijakan

\footnotetext{
${ }^{4}$ Imam Syaukani dan A. Ahsin Thohari, Dasar-dasar Politik Hukum, (Jakarta: Rajawali Press, 2003), hlm. 32.

${ }^{5}$ Bagir Manan, Teori dan Pilitik Konstitusi, (Yogyakarta: UII Press, 2003), hlm. 180-181.
} 
(pembentukan) hukum yurisprudensi atau putusan hukum; dan (c) kebijakan terhadap peraturan tidak tertulis lainnya. Adapun politik penegakan hukum merupakan kebijakan yang bersangkutan dengan; (a) kebijakan di bidang peradilan; dan (b) kebijakan di bidang pelayanan hukum.

Konstruksi politik hukum dalam pemilihan politik hukum Indonesia terdiri atas dua model, terdapat politik hukum yang tetap dan tidak berubah (permanen), dan pada sisi lain terdapat politik hukum yang dapat berubahubah sesuai kebutuhan dalam jangka waktu tertentu. Adapun politik hukum Indonesia yang tidak berubah adalah meliputi :

1. adanya satu kesatuan sistem hukum Indonesia;

2. sistem hukum nasional dibangun berdasarkan Pancasila dan UUD Tahun 1945;

3. keadilan hukum kepada warga negara;

4. pembentukan hukum yang memperhatikan kemajemukan masyarakat;

5. hukum adat diakui keberadaannya sepanjang masih berlaku;

6. pembentukan hukum berdasarkan partisipasi masyarakat;

7. hukum dibuat dan ditegakkan demi kesejahteraan umum, demokratis berlandaskan hukum dan konstitusi.

Dalam bidang konstitusi, K.C. Wheara sebagaimana dikutip Mahfud $\mathrm{MD}^{6}$ menyebutkan bahwa "...a constitution is indeed the resultant of parallelogram of forces-political, economiand sosial-which operate at that of it adoption..." Makna demikian berarti,

Pertama, karena konstitusi merupakan produk situasi atau keadaan bangsa pada waktu tertentu maka konstitusi itu dapat berubah jika situasi dan kondisi masyarakat sudah berubah dan melahirkan tuntutan-tuntutan baru.... kedua, isi konstitusi sebenarnya merupakan kesepakatan tentang pilihan politik. Ia tidak dapat secara kategoris dikatakan benar atau salah atau dikatakan baik atau jelek... ketiga, isi konstitusi tidak harus mengikuti teori tertentu atau sistem yang berlaku di negara tertentu. Isi konstitusi dapat dipilih sendiri oleh bangsa dan negara yang membuatnya sesuai dengan kebutuhan domestiknya masing-masing.

UUD 1945 sebagai produk kesepakatan politik di era perjuangan fisik didesain sebagai konstitusi sederhana, singkat tetapi diharapkan fleksibel, dapat menyesuaikan dengan keadaan saat itu, yang sampai pada waktunya menurut Soekarno akan dilakukan perubahan dan pembentukan UUD yang lebih baik lagi. Demikian pula menurut Harun al Rasyid sebagaimana dikutip Muhtadi, ${ }^{7}$ UUD 1945 masih bersifat sementara sampai kemudian ditetapkan oleh lembaga yang dibentuk konstitusi untuk itu. Namun dalam

\footnotetext{
${ }^{6}$ AM Fatwa, Potret Konstitusi Pasca Amandemen UUD 1945, (Jakarta: Kompas, 2009), hlm. ii.

${ }^{7}$ Muhtadi, Asas Musyawarah Mufakat dalam UUD 1945, Skripsi Fakultas Hukum Univ. Tadulako (Palu: FH Untad, 2001), hlm. 57.
} 
perkembangannya, ketersingkatan konstitusi tersebut dijadikan sebagai instrumen hukum tertingi yang melanggengkan kekuasaan setiap rezim yang berkuasa, sehingga kemudian justru melahirkan negara dengan demokrasi terpimpin dan demokrasi Pancasila, yang keduanya serupa sama-sama tidak memberikan perlindungan dan pemenuhan hak-hak masyarakat.

Praktik ketatanegaraan berdasarkan UUD 1945 asli di bawah rezim Soeharto pada akhirnya mengantarkan pada upaya-upaya perubahan konstitusi yang didasarkan pada $:^{8}$

1. UUD Tahun 1945 membentuk struktur kekuasaan ketatanegaraan yang bertumpu pada kekuasaan tertinggi di tangan MPR yang sepenuhnya melakukan kedaulatan rakyat; yang berakibat tidak terjadinya saling mengawasi dan saling mengimbangi pada institusi kenegaraan;

2. UUD Tahun 1945 memberikan kekuasaan yang sangat besar kepada pemegang kekuasaan eksekutif (Presiden);

3. UUD Tahun 1945 mengandung pasal-pasal yang terlalu "luwes', sehingga dapat menimbulkan lebih dari satu penafsiran (multitafsir);

4. UUD Tahun 1945 terlalu banyak memberikan kewenangan kepada kekuasaan Presiden untuk mengatur hal-hal penting dengan undangundang; dan

5. rumusan UUD Tahun 1945 tentang semangat penyelenggaraan negara belum cukup didukung ketentuan konstitusi yang memuat aturan dasar tentang kehidupan yang demokratis, supremasi hukum, pemberdayaan rakyat, penghormatan HAM, dan otonomi daerah.

Dalam pidato penutupan Sidang Tahunan MPR tahun 2002, Amien Rais sebagaimana dikutip Saldi Isra9 ${ }^{9}$ menyatakan bahwa :

"Reformasi konstitusi yang telah dilakukan merupakan suatu langkah berdemokrasi dalam upaya menyempurnakan UndangUndang Dasar (UUD) 1945 menjadi konstitusi yang demokratis, konstitusi yang sesuai dengan semangat zaman, konstitusi yang mampu mewadahi dinamika bangsa dan perubahan zaman pada masa yang akan datang. Dengan UUD yang telah diamendir, dihadapan kita telah terbentang suatu era Indonesia baru yang lebih demokratis dan lebih maju.

\footnotetext{
${ }^{8}$ Majelis Permusyawaratan Rakyat Republik Indonesia, Panduan Memasyarakatkan UndangUndang Dasar Negara Republik Indonesia Tahun 1945: Sesuai dengan Urutan Bab, Pasal dan Ayat, (Jakarta: Sekretariat Jenderal MPR-RI, 2005,) hlm. 6-8. Lihat juga A. Mukhtie Fadjar, Reformasi Konstitusi Dalam Transisi Pragmatik, dalam Bambang Widjoyanto, Saldi Isra, dan Marwan Mas (editor) : Konstitusi Baru Melalui Komisi Konstitusi Independen, (Jakarta: Sinar Harapan, 2002).

${ }^{9}$ Saldi Isra, Reformasi Hukum Tata Negara Pasca Amandemen UUD 1945, (Padang: Andalas University, 2006), hlm. 196.
} 
Penulisan ini menggunakan pendekatan normatif. Penulisan ini diharapkan dapat menemukan politik hukum permanen dan insidentil dalam pengawasan hakim konstitusi.

\section{B. Pembahasan}

\section{Urgensi Pengawasan terhadap Hakim Konstitusi}

Perkembangan kenegaraan menunjukkan bahwa tiada satupun negara yang tidak memunyai konstitusi. Inggris sekalipun yang sering dijadikan sebagai contoh negara tanpa konstitusi pada prinsipnya mengakui dan mempraktikkan ketatanegaraannya dengan konstitusi, meskipun bentuknya tidak sebagaimana Undang-Undang Dasar pada umumnya yang tertulis.

A.A.H. Struycken menyebutkan bahwa UUD sebagai konstitusi tertulis merupakan dokumen formal yang didalamnya memuat $:{ }^{10}$

1. hasil perjuangan politik bangsa di waktu yang lampau;

2. tingkat-tingkat tertinggi perkembangan ketatanegaraan bangsa;

3. pandangan tokoh-tokoh bangsa yang hendak diwujudkan, baik untuk waktu sekarang maupun untuk masa yang akan datang; dan

4. suatu keinginan, dengan mana perkembangan kehidupan ketatanegaraan bangsa hendak dipimpin.

Adapun kelaziman yang ditemukan sebagai materi muatan UUD setidaknya meliputi tiga hal pokok, yaitu : ${ }^{11}$

1. adanya jaminan terhadap hak-hak asasi manusia dan warganya;

2. ditetapkannya susunan ketatanegaraan suatu negara yang bersifat fundamental; dan

3. adanya pembagian dan pembatasan tugas ketatanegaraan yang juga bersifat fundamental.

Namun demikian, tidak semua materi muatan UUD adalah kaidah kenegeraan. Melainkan juga terdapat kaidah yang menjadi dasar bagi hukum administrasi, pidana dan lain-lain, ${ }^{12}$ termasuk didalamnya mengatur etika kehidupan berbangsa dan bernegara, serta perilaku penyelenggara negara

10 Taufiqurrahman Syahuri, Hukum Konstitusi; Proses dan Prosedur Perubahan UUD di Indonesia 1945-2002 Serta Perbandingannya dengan Konstitusi Negara Lain di Dunia, (Bogor Selatan: Ghalia Indonesia, 2006), hlm. 15, lihat juga Moh. Kusnardi dan Harmaily Ibrahim, Pengantar Hukum Tata Negara Indonesia, (Jakarta: Pusat Studi HTN Fak. Hukum UI, 1988), hlm. 67., lihat pula A. Mukti Arto, Konsepsi Ideal Mahkamah Agung; Redefenisi Peran dan Fungsi Mahkamah Agung untuk Membangun Indonesia Baru, (Yogyakarta: Pustaka Pelajar, 2001), hlm. 13.

${ }^{11}$ Sri Soemantri, M, Ketetapan MPR(S) Sebagai Salah Satu Sumber Hukum Tata Negara, Remadja Karya CV, Bandung, hlm. 2, lihat juga Taufiqurrahman Syahuri, Op.Cit., hlm. 16, lihat juga A.Mukti Arto, Op.Cit., hlm. 13-14.

${ }^{12}$ Bagir Manan, Hubungan Ketatanegaraan Mahkamah Agung dan Mahkamah Konstitusi dengan Komisi Yudisial (Suatu Pertanyaan?), Varia Peradilan Majalah Hukum Tahun ke XXI Nomor 244, Maret, IKAHI, Jakarta, 2006, hlm. 4. 
adalah salah satu muatan konstitusi. Karena itu, membaca UUD juga seharusnya dilakukan sebagai moral and philosophical reading of the constitution. ${ }^{13}$

Salah satu materi muatan UUD Tahun 1945 sebagaimana diatur dalam Pasal 24 ayat (2) dan Pasal 24C adalah pembentukan Mahkamah Konstitusi sebagai salah satu penegak hukum dan keadilan, yang harus memiliki integritas dan kepribadian yang tidak tercela, adil, negarawan yang menguasai konstitusi dan ketatanegaraan, serta tidak merangkap sebagai pejabat negara. Dalam pendekatan berbeda, prasyarat tersebut menghendaki hakim konstitusi untuk menjaga dan menegakkan kehormatan, keluhuran martabat, serta perilaku sebagai penyelenggara negara.

Namun demikian, tertangkapnya Ketua Mahkamah Konsitusi (MK) Akil Mochtar, oleh Komisi Pemberantasan Korupsi (KPK) seakan membenarkan terjadinya pembagian dan pemencaran kejahatan pada setiap organ kekuasaan negara di semua tingkatan (dari trias politika menjadi trias koruptika) ${ }^{14}$ sekaligus mengkonfirmasikan perlunya mempertimbangkan kembali keterlibatan lembaga lain dalam mengawasi perilaku hakim konstitusi $^{15}$ setelah sebelumnya dibatalkan melalui Putusan MK No. 005/PUU-IV/2006. ${ }^{16}$

Inkonstitusionalitas pengawasan Komisi Yusidial $(\mathrm{KY}){ }^{17}$ menurut MK dalam putusannya didasarkan pada dua legal reasioning utama, yaitu problematika interpretasi pembentuk konstitusi (original intent) dan sistematis, ${ }^{18}$ yang keduanya menurut mahkamah terjadi inskonsistensi antara

${ }^{13}$ Jimly Asshidiqie, Peradilan Etik dan Etika Konstitusi, (Jakarta: Sinar Grafika, 2014), hlm. 233.

${ }^{14}$ Malik, Perppu Pengawasan Hakim MK Versus Putusan Final MK, Jurnal Konstitusi, Volume 10, Nomor 4. Desember, (Jakarta: Kepaniteraan dan Sekretariat Jenderal MK, 2013), hlm. 580.

${ }^{15}$ Cetak biru MK membenarkan adanya keterlibatan institusi non peradilan yang mengawasi kinerja lembaga tersebut dan aparaturnya. MK-RI, Cetak Biru Mahkamah Konstitusi Republik Indonesia, (Jakarta: Sekretariat Jenderal MK RI, 2004), hlm. 15.

16 Putusan Nomor 005/PUU-IV/2006 tentang Pengujian Undang-Undang Nomor 22 Tahun 2004 tentang Komisi Yudisial dan Undang-Undang Nomor 4 Tahun 2004 tentang Kekuasaan Kehakiman terhadap Undang-Undang Dasar Negara Republik Indonesia Tahun 1945.

${ }^{17}$ Lihat Pasal 21 Undang-undang Nomor 22 Tahun 2004 tentang Komisi Yudisial jo Pasal 34 ayat (3) Undang-undang Nomor 4 Tahun 2004 tentang Kekuasaan Kehakiman. Penghapusan wewenang KY mengawasi perilaku hakim konstitusi setelah putusan MK No. 005/PUU-IV/2006 diadopsi dalam Pasal 44 Undang-undang No. 48 tahun 2009 tentang Kekusaan Kehakiman (LNRI Tahun 2009 Nomor 157, TLNRI Nomor 5076), serta penghapusan wewenang KY mengusulkan penjatuhan sanksi bagi hakim kepada Pimpinan MA/MK dengan menghapus Pasal 21 dalam Undang-undang Nomor 18 Tahun 2011 tentang Perubahan terhadap Undang-undang Nomor 22 Tahun 2004 tentang Komisi Yudisial (LNRI Tahun 2011 Nomor 106, TLNRI Nomor 5250).

${ }^{18}$ Lihat Putusan MKRI Nomor 005/PUU-IV/2006, hlm. 173-176. 
penormaan Pasal 24B ayat (1) Undang-Undang Dasar (UUD) Tahun 1945 dengan Undang-undang Nomor 22 Tahun 2004 tentang Komisi Yudisial ${ }^{19}$ serta Undang-undang Nomor 4 Tahun 2004 tentang Kekuasaan Kehakiman ${ }^{20}$ terkait pelaksanaan wewenang lain dalam rangka menjaga dan menegakkan kehormatan, keluhuran martabat, serta perilaku hakim, sehingga pengawasan KY terhadap hakim konstitusi dikualifikasikan bertentangan dengan UUD Tahun 1945, tetapi sebaliknya, Hakim Agung dan hakim badan peradilan dalam lingkungan Mahkamah Agung menjadi objek pengawasan KY. ${ }^{21}$

Guna menghindari kekosongan hukum dan organ pengawas perilaku hakim konstitusi, dibentuk pengawas permanen, Majelis Kehormatan Hakim Konstitusi (MKHK) berdasarkan Pasal 27A Undang-undang Nomor 8 Tahun 2011 tentang Perubahan atas Undang-undang Nomor 23 Tahun 2004 tentang Mahkamah Konstitusi ${ }^{22}$ beranggotakan 5 orang $^{23}$ yang kemudian dinyatakan illegal kembali oleh Putusan MK Nomor 49/PUU-IX/201124 dengan mendalilkan bahwa adanya unsur DPR, unsur pemerintah, dan hakim agung berpotensi menimbulkan konflik kepentingan karena DPR, Pemerintah dan Mahkamah Agung, serta Komisi Yudisial dapat menjadi pihak yang berperkara di Mahkamah Konstitusi. ${ }^{25}$ Lebih dari itu, MK mendalilkan bahwa keanggotaan MKHK tersebut tidak memberi jaminan kemandirian dan imparsialitas mahkamah, karenanya MK bersikukuh membentuk MKHK tersendiri dengan keanggotaan selain dari MK juga berasal dari unsur lain yang independen dan tidak partisan. ${ }^{26}$

Ketiadaan kembali pengawas perilaku hakim konstitusi, secara internal MK membentuk Majelis Kehormatan Mahkamah Konstitusi (MKMK) melalui Peraturan Mahkamah Konstitusi (PMK) Nomor 1 Tahun 2013, beranggotakan 5 (lima) orang, terdiri dari unsur hakim konstitusi, komisioner KY, mantan pimpinan lembaga negara, mantan hakim konstitusi/hakim agung dan guru besar senior ilmu hukum. Keanggotaan tersebut menghilangkan unsur DPR, pemerintah dan hakim agung sebagaimana dimaksud dalam Pasal 27A ayat (2) UU MK. MKMK dapat

${ }^{19}$ Lembaran Negara RI (LNRI) Tahun 2004 Nomor 89, Tambahan Lembaran Negara RI (TLNRI) Nomor 4415.

${ }^{20}$ LNRI Tahun 2004 Nomor 8, TLNRI Nomor 4397.

${ }^{21}$ Ibid., hlm. 173-176.

${ }^{22}$ LNRI Tahun 2011 Nomor 70, TLNRI Nomor 5226.

${ }^{23}$ Pasal 27A ayat (2) UU No. 8/2011, MKHK beranggotakan 5 (lima) orang, masing-masing seorang dari dari hakim konstitusi, komisioner KY, unsur DPR, unsur pemerintah bidang hukum dan hakim agung.

${ }^{24}$ Putusan Nomor 49/PUU-IX/2011 tentang Pengujian Undang-undang Nomor 8 Tahun 2011 tentang Perubahan Atas Undang-undang Nomor 23 Tahun 2004 tentang Mahkamah Konstitusi terhadap UUD Tahun 1945 tanggal 14 Oktober 2012.

${ }^{25}$ Ibid., hlm. 72.

${ }^{26}$ Ibid., hlm. 73. 
dibentuk berdasarkan permintaan hakim terlapor, ataupun sebagai instrumen yang dibentuk atas dasar laporan dan/atau infromasi untuk kemudian diplenokan dalam rapat tertutup. ${ }^{27}$

Akan tetapi, tertangkapnya Ketua MK aktif pada 2 Oktober 2013 mementahkan legal reasioning Putusan MK Nomor 49/PUU-IX/2011 serta memberikan jawab atas dugaan tidak efektifnya lembaga pengawas internal dalam lembaga peradilan, ${ }^{28}$ sekaligus menunjukkan kelemahan sistem pengawasan internal yang belum ditemukan solusinya. ${ }^{29}$

Bagi Presiden, tertangkapnya ketua MK diterjemahkan sebagai kondisi yang memenuhi kaidah hal ikhwal kegentingan yang memaksa sebagaimana dimaksud Pasal 22 ayat (1) UUD Tahun 1945, sehingga diambil langkah konstitusional menyelamatkan lembaga melalui Peraturan Pemerintah Pengganti Undang-undang (Perppu) Nomor 1 Tahun 2013 tentang Perubahan Kedua Atas Undang-undang Nomor 24 Tahun 2003 tentang Mahkamah Konstitusi, ${ }^{30}$ untuk selanjutnya ditetapkan oleh Dewan Perwakilan Rakyat (DPR) menjadi Undang-undang Nomor 4 Tahun 2014 tentang Penetapan Perppu Nomor 1 Tahun 2013 tentang Perubahan Kedua Atas Undang-undang Nomor 24 Tahun 2003 tentang Mahkamah Konstitusi Menjadi Undang-Undang. ${ }^{31}$

Maksud hal ikhwal kegentingan yang memaksa dalam Perppu secara terang benderang (expressis verbis) diletakkan dalam dua pertimbangan mendasar :

1. bahwa berdasarkan Pasal 24C ayat (5) Undang-Undang Dasar Negara Republik Indonesia Tahun 1945, hakim konstitusi harus memiliki integritas dan kepribadian yang tidak tercela, adil, dan negarawan yang menguasai konstitusi dan ketatanegaraan serta tidak merangkap jabatan sebagai pejabat negara;

2. bahwa untuk menyelamatkan demokrasi dan negara hukum Indonesia serta untuk mengembalikan kewibawaan dan kepercayaan masyarakat terhadap Mahkamah Konstitusi sebagai lembaga negara yang menjalankan fungsi menegakkan Undang-Undang Dasar, perlu dilakukan perubahan terhadap Undang-Undang Nomor 24 Tahun 2003 tentang Mahkamah Konstitusi sebagaimana telah diubah dengan Undang-Undang

\footnotetext{
${ }^{27}$ Lihat Pasal 12 dan 13 PMK No. 1/2013.

${ }^{28}$ Mahkamah Agung, Cetak Biru Pembaruan Mahkamah Agung RI, (Jakarta: Leip-MA, 2003), hlm. 93. Lihat juga Yohanes Usfunan, Pengawasan Hakim, dalam http://www.kompas.com/kompas-cetak /0703/15/opini/3369799.htm , (terakhir kali dikunjungi pada 21 Mei 2014 jam 13.20 WIB).

${ }^{29}$ Dian Rosita, Mengkaji Ulang Konsep Rule of Law dalam Pembaharuan Peradilan di Indonesia, Jurnal Konstitusi Vol. 1 No. 1 November, (Jakarta: Mahkamah Konstitusi, 2008), hlm. 6-20.

${ }^{30}$ LNRI Tahun 2013 Nomor 167, TLNRI Nomor 5456.

${ }^{31}$ LNRI Tahun 2014 Nomor 167, TLNRI Nomor 5456.
} 
Nomor 8 Tahun 2011 tentang Perubahan Atas Undang-Undang Nomor 24 Tahun 2003 tentang Mahkamah Konstitusi, terutama terhadap ketentuan mengenai syarat dan tata cara seleksi, pemilihan, dan pengajuan calon hakim konstitusi serta pembentukan majelis kehormatan hakim konstitusi.

Salah satu substansi materi Perppu dibentuknya Majelis Kehormatan Hakim Konstitusi sebagai lembaga penjaga kehormatan dan perilaku hakim konstitusi, ${ }^{32}$ yang dibentuk MK bersama-sama dengan $\mathrm{KY},{ }^{33}$ beranggotakan 5 (lima) orang, ${ }^{34}$ dengan kewenangan :

1. memanggil hakim konstitusi yang diduga melakukan pelanggaran kode etik untuk memberikan penjelasan dan pembelaan;

2. memanggil pelapor, saksi, dan/atau pihak lain yang terkait untuk dimintai keterangan, termasuk untuk dimintai dokumen atau bukti lain; dan

3. memberikan sanksi kepada hakim konstitusi yang terbukti melanggar kode etik. ${ }^{35}$

Berbeda dengan semangat Perppu yang mendorong keterlibatan KY dalam pembentukan MKHK, secara tegas MK menolak keterlibatan KY dengan membentuk Dewan Etik Hakim Konstitusi melalui PMK Nomor 2 Tahun 2013 tentang Dewan Etik Hakim Konstitusi yang beranggotakan 3 (tiga) orang masing-masing berasal dari mantan hakim konstitusi, akademisi dan tokoh masyarakat, dengan durasi masa jabatan selama 3 (tiga) tahun. Dewan Etik inilah yang kemudian berhak merekomendasikan pembentukan Majelis Kehormatan Hakim Konstitusi apabila untuk mengadili hakim terlapor yang melakukan pelanggaran berat atau hakim telah mendapatkan teguran tulis dan/atau lisan sebanyak 3 (tiga) kali.

Bersamaan dengan pengesampingan MKHK bentukan Perppu dengan Dewan Etik buatan PMK No. 2/2013, keberadaan Perppu yang lahir dari semangat mempertahankan dan mengembalikan harkat martabat dan kehormatan MK, namun menimbulkan polemik ketatanegaraan. Selain diduga mereduksi kewenangan lembaga negara yang diberikan konstitusi, juga telah merubah Pasal 24B dan 24C UUD Tahun 1945 dengan norma yang lebih rendah dari konstitusi itu sendiri sehingga dianggap bertentangan dengan UUD Tahun 1945. Kondisi demikian yang pada akhirnya menjadi argumentasi hukum diajukan pengujian derajat konstitusionalitasnya di MK.

Pada Kamis 13 Februari 2014, MK mengabulkan permohonan pengujian Undang-undang Nomor 4 Tahun 2014 dengan Putusan Nomor 1-

\footnotetext{
${ }^{32}$ Lihat Pasal 1 angka 4 Perppu.

${ }^{33}$ Lihat Pasal 27A ayat (4) Perppu.

${ }^{34}$ Pasal 27A ayat (5) Perppu menyebutkan anggota MKHK terdiri dari seorang mantan hakim konstitusi, seorang praktisi hukum, dua orang akademisi yang salah satu atau keduanya berlatar belakang di bidang hukum dan seorang tokoh masyarakat.

${ }^{35}$ Lihat Pasal 27A ayat (9) Perppu.
} 
2/PUU-XII/2014 tentang Pengujian Undang-undang Nomor 4 Tahun 2014 tentang Penetapan Perppu Nomor 1 Tahun 2013 tentang Mahkamah Konstitusi Menjadi Undang-undang, dengan menyatakan bahwa Undangundang Nomor 4 Tahun 2014 bertentangan dengan UUD Tahun 1945, tidak memunyai kekuatan hukum mengikat serta memberlakukan kembali Undang-undang Nomor 24 Tahun 2003 tentang Mahkamah Konstitusi sebagaimana diubah dengan Undang-undang Nomor 8 Tahun 2011 tentang Perubahan Kedua Atas Undang-undang No. 24 Tahun 2003 Tentang Mahkamah Konstitusi. ${ }^{36}$ Dengan demikian, keberadaan organ rekrutmen hakim MK (panel ahli), Majelis kehormatan Hakim MK, dan syarat-syarat lain yang diatur dalam Perppu dinyatakan tidak mempunyai kekuatan mengikat.

Berbeda dengan Putusan MK No. 005/PUU-IV/2006 yang menggunakan argumentasi sistematika dan original intent pembuat UUD Tahun 1945, dan Putusan MK No. 49/PUU-IX/2011 dengan dalil tidak adanya jaminan kemandirian dan kenetralan MKHK karena keanggotaannya tidak netral, maka dalam Putusan No. 1-2/PUU-IX/2014 penghapusan kembali lembaga pengawas hakim konsitusi yang melibatkan KY didasarkan pada penerapan prinsip check and balances yang tidak tepat diterapkan dalam kekuasaan kehakiman yang merdeka, tetapi mengatur relasi legislatif dan eksekutif, ${ }^{37}$ serta menggunakan terminologi terjadinya penyelundupan hukum yang dilakukan Perppu karena pengabaian terhadap Putusan No. 005/PUU-IV/2006, ${ }^{38}$ lebih dari itu MK berpendapat syarat objektifitas dari hak subjektifitas Presiden menerbitkan Perppu tidak terpenuhi, ${ }^{39}$ yaitu tidak adanya indikasi kegentingan yang memaksa yang harus diselesaikan sesegera mungkin, tidak pula memunyai akibat prompt immediatelly (sontak segera) untuk memecahkan permasalahan hukum sebagaimana yang seharusnya terdapat dalam pertimbangan Perppu No.1 Tahun 2013. ${ }^{40}$ Dengan demikian, penghapusan kembali lembaga pengawas perilaku hakim konstitusi yang melibatkan lembaga lain dapat menjadi presiden buruk

\footnotetext{
${ }^{36}$ Putusan MK No. 1-2/PUU-IX/2014, hlm. 121-122.

${ }^{37}$ Ibid., hlm. 110.

${ }^{38}$ Ibid., hlm. 115.

${ }^{39}$ Putusan MK No. 138/PUU-VII/2009 menetapkan tiga syarat kegentingan yang memaksa sebagaimana dimaksud Pasal 22 ayat (1) UUD Tahun 1945, yaitu

1.adanya keadaan yaitu kebutuhan mendesak untuk menyelesaikan masalah hukum secara cepat berdasarkan undang-undang;

2.undang-undang yang dibutuhkan tersebut belum ada sehingga terjadi kekosongan hukum, atau ada undang-undang tetapi tidak memadai;

3.kekosongan hukum tersebut tidak dapat diatasi dengan cara membuat undang-undang secara prosedural biasa karena akan memerlukan waktu yang cukup lama sedangkan keadaan mendesak tersebut perlu kepastian untuk diselesaikan.

${ }^{40}$ Putusan No. 1-2/PUU-IX/2014, hlm. 119-120.
} 
penegakan hukum, yang dapat menyuburkan tirani yudisial, dan tirani kekuasaan kehakiman, ${ }^{41}$ yang dijalankan Mahkamah Konstitusi secara monopolistik.

Akan tetapi, untuk menjamin kepastian hukum dan agar tidak terjadinya kekosongan hukum dan lembaga pengawas perilaku hakim konstitusi kembali, pada 18 Maret 2014 MK menerbitkan PMK Nomor 2 Tahun 2014 tentang Majelis Kehormatan Mahkamah Konstitusi (MKHK) yang sekaligus menyatakan tidak berlaku PMK 1 Tahun 2013 dan PMK 2 Tahun 2013. MKHK model PMK 2 Tahun 2014 memunyai sejumlah perbedaan mendasar dengan bentuk PMK 1 Tahun 2013, sedangkan Dewan Etik yang diadopsi PMK 2 Tahun 2014 adalah serupa dengan yang dimaksud PMK 2 Tahun 2013 dengan penegasan akademisi yang dimaksud PMK 2 Tahun 2013 menjadi guru besar ilmu hukum. Tabel berikut mendeskripsikan perbedaan dan persamaan di antara lembaga pengawas perilaku hakim konstitusi sejak 2004.

Tabel 1

Lembaga Pengawas Perilaku Hakim Konstitusi

\begin{tabular}{|c|c|c|c|}
\hline Lembaga & $\begin{array}{l}\text { Kedudukan dan } \\
\text { Masa Jabatan }\end{array}$ & $\begin{array}{c}\text { Pembentuk } \\
\text { dan Anggota }\end{array}$ & Wewenang \\
\hline (1) & (2) & (3) & (4) \\
\hline $\begin{array}{l}\text { Komisi Yudisial } \\
\text { (Putusan MK } \\
\text { No. 005/PUU- } \\
\text { IV/2006 } \\
\text { menghapus } \\
\text { wewenang KY } \\
\text { mengawasi } \\
\text { dan/atau }\end{array}$ & \begin{tabular}{l}
\multicolumn{3}{l}{ Organ konstitusi } \\
Pasal 24B UUD \\
Tahun 1945
\end{tabular} & $\begin{array}{l}\text { Diangkat dan } \\
\text { diberhentikan } \\
\text { oleh Presiden } \\
\text { dengan } \\
\text { persetujuan } \\
\text { Dewan } \\
\text { Perwakilan } \\
\text { Rakyat. }\end{array}$ & $\begin{array}{l}\text { "...dan memunyai } \\
\text { wewenang lain dalam } \\
\text { rangka menjaga dan } \\
\text { menegakkan } \\
\text { kehormatan, } \\
\text { keluhuran martabat, } \\
\text { serta perilaku } \\
\text { hakim". }\end{array}$ \\
\hline $\begin{array}{l}\text { menjatuhkan } \\
\text { sanksi bagi } \\
\text { hakim } \\
\text { konstitusi) }\end{array}$ & $\begin{array}{l}\text { UU } 22 \text { Tahun } 2004 \\
\text { jo UU } 18 \text { Tahun } \\
2011 \\
\text { Masa jabatan 5 } \\
\text { tahun dan dapat } \\
\text { dipilih lagi untuk } \\
\text { satu periode } \\
\text { berikutnya. }\end{array}$ & $\begin{array}{l}\text { Beranggotakan } 7 \\
\text { (tujuh) orang: } \\
2 \text { orang mantan } \\
\text { hakim; } \\
2 \text { orang praktisi } \\
\text { hukum; } \\
2 \text { orang } \\
\text { akademisi; dan } \\
1 \text { orang tokoh }\end{array}$ & $\begin{array}{lr}\text { Menegakkan } & \\
\text { kehormatan } & \text { dan } \\
\text { keluhuran } & \text { martabat } \\
\text { serta } & \text { menjaga } \\
\text { perilaku } & \text { hakim } \\
\text { dengan } & \text { cara } \\
\text { melakukan } & \\
\text { pengawasan terhadap } \\
\text { perilaku hakim dalam }\end{array}$ \\
\hline
\end{tabular}

${ }^{41}$ Paulus Effendi Lotulung, Presfektif Fungsi MA ke Depan, dalam Henry P. Panggabean, Fungsi Mahkamah Agung dalam Praktek Sehari-hari;Upaya Menanggulangi Tunggakan Perkara dan Pemberdayaan Fungsi Pengawasan MA, (Jakarta: Pustaka Sinar Harapan, 2001), hlm. xxxvi. 


\begin{tabular}{|c|c|c|c|}
\hline & & masyarakat & $\begin{array}{l}\text { rangka menegakkan } \\
\text { kehormatan dan } \\
\text { keluhuran martabat } \\
\text { serta menjaga } \\
\text { perilaku hakim. }\end{array}$ \\
\hline $\begin{array}{l}\text { Majelis } \\
\text { Kehormatan } \\
\text { Hakim } \\
\text { Konstitusi }\end{array}$ & $\begin{array}{l}\text { Organ institusional } \\
\text { PMK No. } 1 \text { Tahun } \\
2013 \\
\text { Insidentil Maksimal } \\
90 \text { (sembilan puluh) } \\
\text { hari }(60+30)\end{array}$ & $\begin{array}{l}\text { Dibentuk MK } \\
\text { beranggotakan } 5 \\
\text { (lima) orang: } \\
1 \text { orang hakim } \\
\text { konstitusi } \\
1 \text { orang pimpinan } \\
\text { KY } \\
1 \text { orang mantan } \\
\text { pimpinan lembaga } \\
\text { negara } \\
1 \text { orang mantan } \\
\text { hakim konstitusi } \\
\text { atau hakim agung } \\
1 \text { orang guru } \\
\text { besar ilmu hukum }\end{array}$ & $\begin{array}{l}\text { Memeriksa dan } \\
\text { mengambil keputusan } \\
\text { terhadap laporan } \\
\text { dan/atau informasi } \\
\text { adanya pelanggaran } \\
\text { hakim konstitusi } \\
\text { terhadap Pasal 23 (2) } \\
\text { huruf b, c, d, e, f, g, h } \\
\text { atau tidak melakukan } \\
\text { kewajiban dan } \\
\text { melanggar larangan } \\
\text { Pasal 27B UU MK. }\end{array}$ \\
\hline $\begin{array}{l}\text { Majelis } \\
\text { Kehormatan } \\
\text { Hakim } \\
\text { Konstitusi }\end{array}$ & $\begin{array}{l}\text { Organ undang- } \\
\text { undang } \\
\text { Perppu No.1 Tahun } \\
2013 \text { jo UU } 4 \\
\text { Tahun 2014 } \\
\text { Tetap } 5 \text { tahun tidak } \\
\text { dapat dipilih } \\
\text { kembali }\end{array}$ & $\begin{array}{l}\text { Dibentuk MK } \\
\text { bersama KY } \\
\text { beranggotakan } 5 \\
\text { (lima) orang: } \\
1 \text { orang mantan } \\
\text { hakim konstitusi; } \\
1 \text { orang praktisi } \\
\text { hukum; } \\
2 \text { orang akademisi } \\
\text { yang salah satu } \\
\text { atau keduanya } \\
\text { berlatar belakang } \\
\text { hukum; dan } \\
1 \text { orang tokoh } \\
\text { masyarakat. }\end{array}$ & $\begin{array}{l}\text { a. memanggil hakim } \\
\text { konstitusi yang } \\
\text { diduga melakukan } \\
\text { pelanggaran kode } \\
\text { etik untuk } \\
\text { memberikan } \\
\text { penjelasan dan } \\
\text { pembelaan } \\
\text { b. memanggil pelapor, } \\
\text { saksi, dan/atau } \\
\text { pihak lain yang } \\
\text { terkait untuk } \\
\text { dimintai keterangan, } \\
\text { termasuk untuk } \\
\text { dimintai dokumen } \\
\text { atau bukti lain; } \\
\text { c. memberikan sanksi } \\
\text { kepada hakim } \\
\text { konstitusi yang } \\
\text { terbukti melanggar } \\
\text { kode etik. }\end{array}$ \\
\hline $\begin{array}{l}\text { Dewan Etik } \\
\text { Hakim } \\
\text { Konstitusi }\end{array}$ & $\begin{array}{l}\text { Organ institusional, } \\
\text { PMK No. } 2 \text { Tahun } \\
2013 \\
\text { Bersifat tetap, }\end{array}$ & $\begin{array}{l}\text { Dibentuk MK, } \\
\text { beranggotakan } 3 \\
\text { (tiga) orang: } \\
1 \text { orang mantan } \\
\text { hakim konstitusi; }\end{array}$ & $\begin{array}{l}\text { a. Menjaga dan } \\
\text { menegakkan } \\
\text { kehormatan, } \\
\text { keluhuran martabat } \\
\text { dan perilaku }\end{array}$ \\
\hline
\end{tabular}




\begin{tabular}{|c|c|c|c|}
\hline & $\begin{array}{l}\text { dibentuk sampai } \\
\text { terbentuk MKHK } \\
\text { berdasarkan Perppu } \\
\text { No.1 Tahun 2013. }\end{array}$ & $\begin{array}{l}1 \text { orang } \\
\text { akademisi; dan } \\
1 \text { orang tokoh } \\
\text { masyarakat. }\end{array}$ & 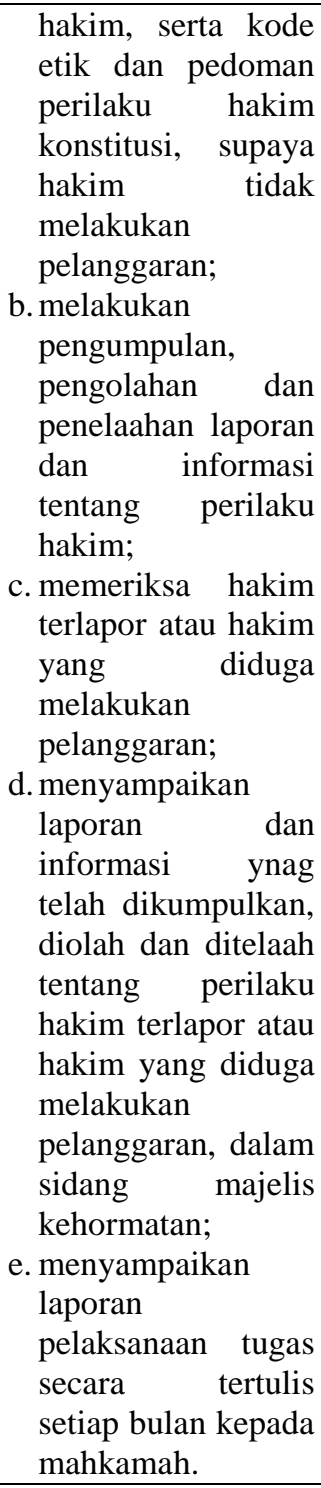 \\
\hline $\begin{array}{l}\text { Majelis } \\
\text { Kehormatan }\end{array}$ & $\begin{array}{l}\text { Organ institusional } \\
\text { PMK } 2 \text { Tahun } 2013\end{array}$ & $\begin{array}{l}\text { Dibentuk atas } \\
\text { usul dewan etik } \\
\text { kepada MK dalam } \\
\text { hal : } \\
\text { a. dewan etik } \\
\text { berpendapat } \\
\text { hakim terlapor/ } \\
\text { hakim terduga } \\
\text { telah }\end{array}$ & $\begin{array}{l}\text { Diatur lebih lanjut } \\
\text { dalam PMK. }\end{array}$ \\
\hline
\end{tabular}




\begin{tabular}{|c|c|c|c|}
\hline & & $\begin{array}{l}\text { melakukan } \\
\text { pelanggaran } \\
\text { berat; } \\
\text { b. hakim terlapor/ } \\
\text { hakim yang } \\
\text { diduga telah } \\
\text { mendapatkan } \\
\text { teguran } \\
\text { lisan/tertulis } \\
\text { sebanyak } 3 \text { kali. }\end{array}$ & \\
\hline \multirow[t]{2}{*}{$\begin{array}{l}\text { Majelis } \\
\text { Kehormatan } \\
\text { Mahkamah } \\
\text { Konstitusi }\end{array}$} & $\begin{array}{l}\text { Organ institusional } \\
\text { PMK No. } 2 \text { Tahun } \\
2014 \\
\text { Bersifat insidentil, } \\
\text { atas dasar dugaan } \\
\text { terjadinya } \\
\text { pelanggaran berat } \\
\text { hakim terlapor. }\end{array}$ & $\begin{array}{l}\text { Dibentuk MK atas } \\
\text { usul dewan etik, } \\
\text { beranggotakan } 5 \\
\text { (lima) orang: } \\
1 \text { orang hakim } \\
\text { konstitusi; } \\
1 \text { orang anggota } \\
\text { KY; } \\
1 \text { orang mantan } \\
\text { hakim konstitusi; } \\
1 \text { orang guru } \\
\text { besar hukum; dan } \\
1 \text { orang tokoh } \\
\text { masyarakat. }\end{array}$ & \begin{tabular}{|l}
\multicolumn{2}{|c}{ Tugas : } \\
a. melakukan \\
pengolahan dan a \\
terhadap laporan \\
yang diajukan \\
dewan etik \\
mengenai dugaan \\
pelanggaran berat \\
yang dilakukan \\
hakim terlapor atau \\
hakim terduga, \\
serta mengenai \\
hakim terlapor atau \\
hakim terduga yang \\
telah mendapatkan \\
teguran lisan \\
sebanyak 3 (tiga) \\
kali; \\
b. menyampaikan \\
keputusan majelis \\
kehormatan kepada \\
MK.
\end{tabular} \\
\hline & & & $\begin{array}{l}\text { Wewenang: } \\
\text { a. memanggil dan } \\
\text { memeriksa hakim } \\
\text { terlapor atau } \\
\text { hakim terduga } \\
\text { yang diajukan } \\
\text { dewan etik untuk } \\
\text { mendapatkan } \\
\text { penjelasan dan } \\
\text { pembelaan, } \\
\text { termasuk meminta } \\
\text { dokumen atau } \\
\text { bukti lain; } \\
\text { b. memanggil dan }\end{array}$ \\
\hline
\end{tabular}




\begin{tabular}{|c|c|c|c|}
\hline & & & $\begin{array}{l}\text { meminta } \\
\text { keterangan } \\
\text { pelapor, saksi } \\
\text { dan/atau pihak } \\
\text { lain yang terkait } \\
\text { dengan dugaan } \\
\text { pelanggaran berat } \\
\text { yang dilakukan } \\
\text { hakim } \\
\text { terlapor/hakim } \\
\text { terduga untuk } \\
\text { mendapat } \\
\text { keterangan, } \\
\text { termasuk meminta } \\
\text { dokumen atau alat } \\
\text { bukti lain; } \\
\text { menjatuhkan } \\
\text { keputusan berupa } \\
\text { sanksi atau } \\
\text { rehabilitasi. }\end{array}$ \\
\hline $\begin{array}{ll}\text { Dewan } & \text { Etik } \\
\text { Hakim } & \\
\text { Konstitusi } & \end{array}$ & $\begin{array}{l}\text { Organ institusional } \\
\text { PMK No. } 2 \text { Tahun } \\
2014 \\
\text { Dipilih oleh panitia } \\
\text { seleksi (Pansel) } \\
\text { independen. } \\
\text { Pansel terdiri dari } 3 \\
\text { (tiga) orang: } \\
1 \text { orang mantan } \\
\text { hakim konstitusi; } \\
1 \text { orang akademisi; } \\
\text { dan orang tokoh } \\
1 \text { orang } \\
\text { masyarakat. } \\
\text { Aggota Pansel } \\
\text { dipilih dalam rapat } \\
\text { pleno hakim yang } \\
\text { tertutup. }\end{array}$ & $\begin{array}{l}\text { Dibentuk MK } \\
\text { terkait laporan } \\
\text { dan/atau } \\
\text { informasi dugaan } \\
\text { pelanggaran } \\
\text { hakim } \\
\text { terlapor/terduga. } \\
\text { Beranggotakan } 3 \\
\text { (tiga) orang: } \\
1 \text { orang mantan } \\
\text { hakim konstitusi; } \\
1 \text { orang guru } \\
\text { besar ilmu } \\
\text { hukum; dan } \\
1 \text { orang tokoh } \\
\text { masyarakat. }\end{array}$ & 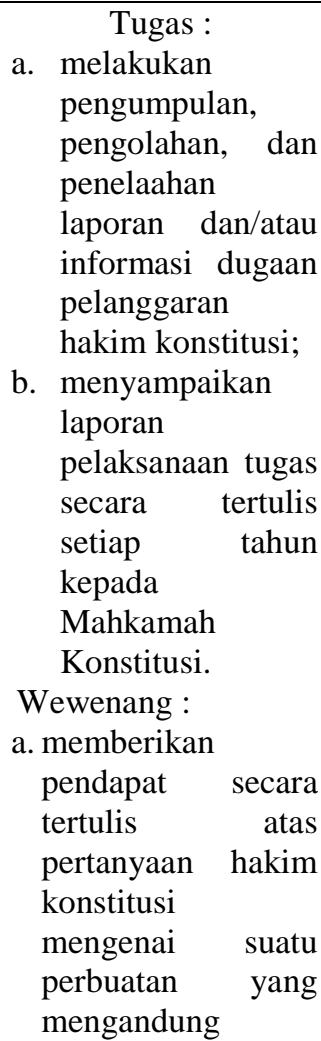 \\
\hline
\end{tabular}




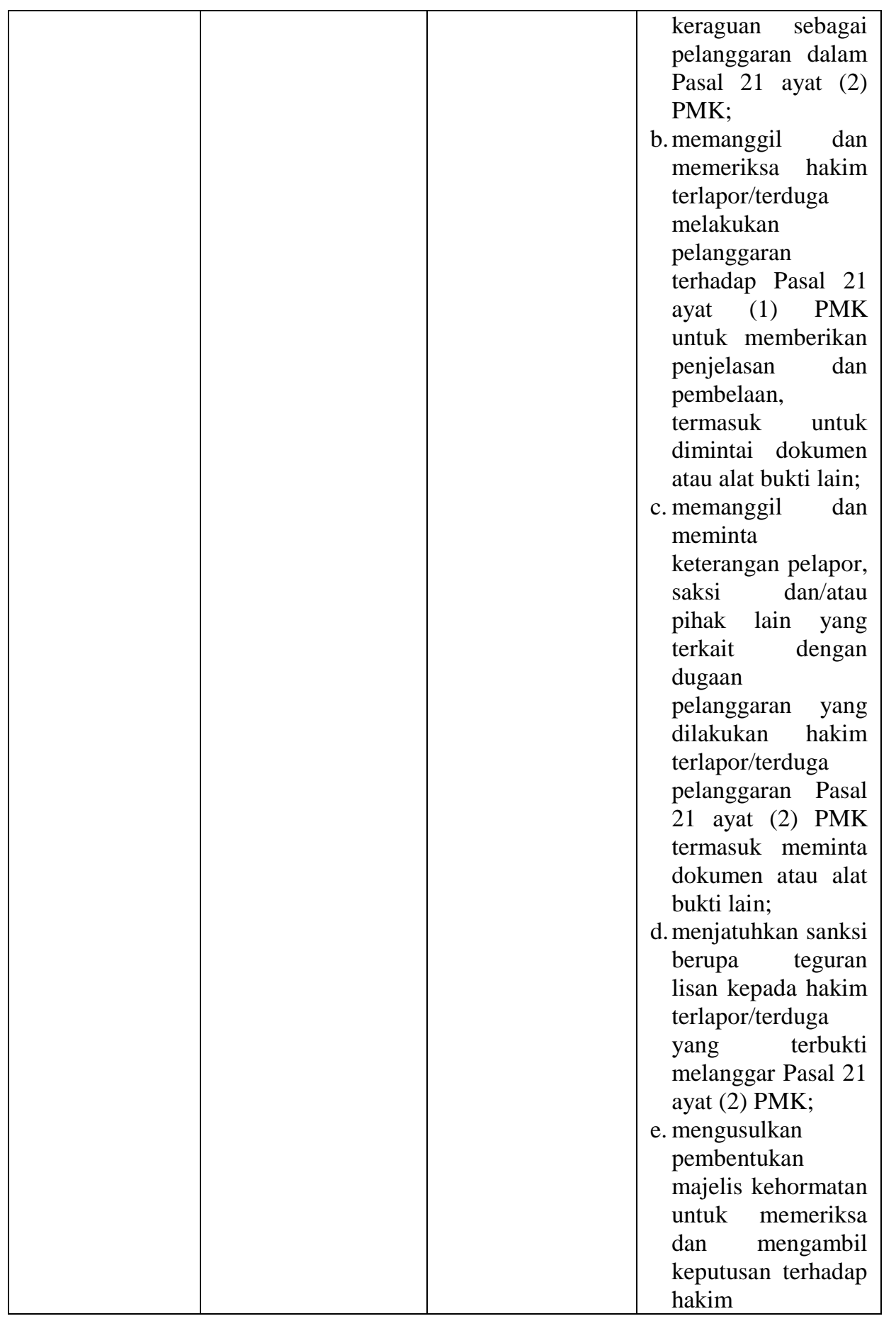




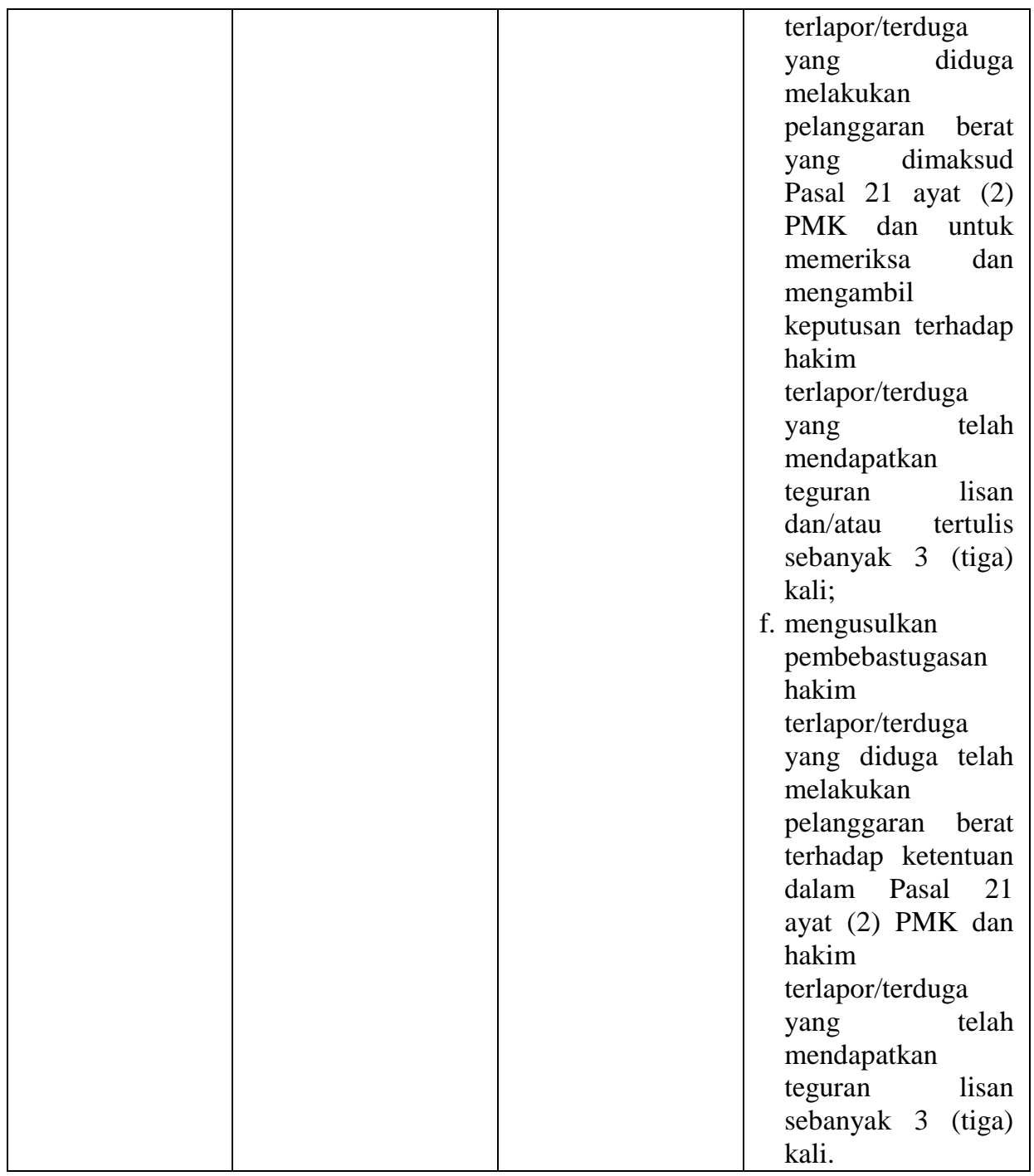

Sumber : data diolah dari UU KY No. 22 Tahun 2004 Jo. UU No. 18 Tahun 2011, UU Kekuasaan Kehakiman No. 4 Tahun 2004 Jo. UU No. 49 Tahun 2009, Putusan MK No. 005/PUU-IV/2006, UU MK No. 24 Tahun 2003 Jo. UU No. 8 Tahun 2011, Putusan MK No. 49/PUU-IX/2011, PMK No. 1 Tahun 203, Perppu No. 1 Tahun 2013 Jo. UU No. 4 Tahun 2014, PMK No. 2 Tahun 2013, Putusan MK No. 1-2/PUU-IX/2014, PMK No. 2 Tahun 2014.

Tabel tersebut menunjukkan bahwa institusional MK sangat rentan terhadap upaya keterlibatan pihak lain dalam mengawasi perilaku hakim konstitusi, dan cenderung menolak setiap tindakan-tindakan yang mengarah 
pada masuknya unsur ekstra yudisial dalam ranah penegakan etika hakim, yang sebenarnya dimaksudkan tidak untuk terlibat dalam mekanisme yudisial.

\section{Penutup}

1. Meskipun terdapat penolakan terhadap adanya campur tangan lembaga non yudisial (extra judicial) dalam pengawasan hakim konstitusi, tetapi telah menjadi pilihan politik hukum yang permanen bahwa dalam rangka menjaga dan menegakkan kehormatan, keluhuran martabat, serta perilaku hakim diperlukan pengawasan terhadap perilaku hakim agar sesuai kode etik dan pedoman perilaku sehingga setiap putusan hakim dilaksanakan dalam rangka menegakkan hukum dan keadilan berdasarkan Pancasila dan UUD Tahun 1945;

2. Politik hukum insidentil pengawasan hakim berdasarkan norma UUD Tahun 1945 adalah :

a. perilaku hakim konstitusi diawasi oleh dewan etik yang dibentuk MK, sedangkan terhadap hakim terlapor atau terduga melakukan pelanggaran kode etika dan/atau pedoman perilaku hakim konstitusi dibentuk Majelis Kehormatan Hakim Konstitusi yang pembentukannya diusulkan dewan etik, dengan tugas melaksanakan dan berfungsi sebagai peradilan etik;

b. putusan MK tidak dapat dilakukan pengawasan yudisial sebagaimana halnya pengawasan putusan pengadilan yang berada di lingkungan MA melalui mekanisme upaya hukum (biasa dan luar biasa). Namun demikian, putusan MK dapat dilakukan masyarakat melalui monitoring terhadap pelaksanaan putusan dimaksud, termasuk koreksi melalui kegiatan akademik tetapi tidak dapat merubah putusan.

\section{Daftar Pustaka}

\section{A. Buku}

Arto, A. Mukti, 2001, Konsepsi Ideal Mahkamah Agung; Redefenisi Peran dan Fungsi Mahkamah Agung untuk Membangun Indonesia Baru, Yogyakarta: Pustaka Pelajar.

Asshiddiqie, Jimly, 2014, Peradilan Etik dan Etika Konstitusi, Jakarta: Sinar Grafika.

Fatwa, AM, 2009, Potret Konstitusi Pasca Amandemen UUD 1945, Jakarta: Kompas.

Isra, Saldi, 2006, Reformasi Hukum Tata Negara Pasca Amandemen UUD 1945, Padang: Andalas University. 
Kusnardi, Moh. dan Ibrahim, Harmaily, 1988, Pengantar Hukum Tata Negara Indonesia, Jakarta: Pusat Studi HTN Fak. Hukum UI.

Mahkamah Agung, Cetak Biru Pembaruan Mahkamah Agung RI, Leip-MA, Jakarta, 2003.

Majelis Permusyawaratan Rakyat Republik Indonesia, 2005, Panduan

Memasyarakatkan Undang-Undang Dasar Negara Republik

Indonesia Tahun 1945: Sesuai dengan Urutan Bab, Pasal dan Ayat,

Jakarta: Sekretariat Jenderal MPR-RI.

Manan, Bagir, 2003, Teori dan Pilitik Konstitusi, Yogyakarta: UII Press.

MD, Mahfud, 1998, Politik Hukum di Indonesia, Jakarta: LP3ES.

MK-RI, 2004, Cetak Biru Mahkamah Konstitusi Republik Indonesia, Jakarta: Sekretariat Jenderal MK RI.

Muhtadi, 2001, Asas Musyawarah Mufakat Daam UUD 1945, Skripsi Fakultas Hukum Univ. Tadulako, Palu: FH Untad.

Panggabean, Henry P., 2001, Fungsi Mahkamah Agung dalam Praktek

Sehari-hari;Upaya Menanggulangi Tunggakan Perkara dan

Pemberdayaan Fungsi Pengawasan MA, Jakarta: Pustaka Sinar Harapan.

Rahardjo, Satjipto, 1986, Imu Hukum, Bandung: Alumni.

Sri Soemantri, M., 1986, Ketetapan MPR(S) Sebagai Salah Satu Sumber Hukum Tata Negara, Bandung: Remadja Karya CV.

Syahuri, Taufiqurrahman, 2006, Hukum Konstitusi; Proses dan Prosedur Perubahan UUD di Indonesia 1945-2002 Serta Perbandingannya Dengan Konstitusi Negara Lain Di Dunia, Bogor: Ghalia Indonesia.

Syaukani, Imam dan Thohari, A. Ahsin, 2003, Dasar-dasar Politik Hukum, Jakarta: Rajawali Press.

Varia Peradilan Majalah Hukum Tahun ke XXI Nomor 244, Maret, IKAHI, 2006, Jakarta.

Widjoyanto, Bambang; Isra, Saldi, dan Mas, Marwan (editor), 2002, Konstitusi Baru Melalui Komisi Konstitusi Independen, Jakarta: Sinar Harapan.

Yasir, Armen, 2014, Hukum Perundang-undangan, Bandar Lampung: Justice Publisher.

\section{B. Peraturan Perundang-undangan}

Peraturan Mahkamah Konstitusi No. 1 Tahun 2013 tentang Dewan Etik Mahkamah Konstitusi.

Peraturan Mahkamah Konstitusi No. 2 Tahun 2013 tentang Majelis Kehormatan Mahkamah Konstitusi

Peraturan Mahkamah Konstitusi No. 2 Tahun 2014 tentang Majelis Kehormatan Mahkamah Konstitusi 
Peraturan Pemerintah Pengganti Undang-undang Nomor 1 Tahun 2013 tentang Perubahan Kedua atas undang-undang Nomor 24 Tahun 2003 tentang Mahkamah Konstitusi.

Putusan MK No. 1-2/PUU-IX/2014 tentang Pengujian Undang-undang Nomor 4 Tahun 2014 tentang Penetapan Perppu Nomor 1 Tahun 2013 tentang Perubahan kedua atas Undang-undang Nomor 24 Tahun 2003 tentang Mahkamah Konstitusi menjadi Undang-undang.

Putusan MK No. 138/PUU-VII/2009 tentang Pengujian Perppu No. 10 Tahun 1999 tentang pemberntasan Tindak Pidana Terorisme terhadap UUD 1945.

Putusan Nomor 005/PUU-IV/2006 tentang Pengujian Undang-Undang Nomor 22 Tahun 2004 tentang Komisi Yudisial dan Undang-Undang Nomor 4 Tahun 2004 tentang Kekuasaan Kehakiman terhadap Undang-Undang Dasar Negara Republik Indonesia Tahun 1945.

Putusan Nomor 49/PUU-IX/2011 tentang Pengujian Undang-undang Nomor

8 Tahun 2011 tentang Perubahan Atas Undang-undang Nomor 23

Tahun 2004 tentang Mahkamah Konstitusi terhadap UUD Tahun 1945.

Undang-undang No. 48 tahun 2009 tentang Kekusaan Kehakiman.

Undang-undang Nomo 24 Tahun 2003 tentang Mahkamah Konstitusi sebagaimana diubah dengan Undang-undang Nomor 8 Tahun 2011 tentang Perubahan atas Undang-undang Nomor 24 Tahun 2003 tentang Mahkamah Konstitusi.

Undang-undang Nomor 22 Tahun 2004 tentang Komisi Yudisial (Lembaran

Negara RI, sebagaimana diubah dengan Undang-undang Nomor 18

Tahun 2011 tentang Perubahan terhadap Undang-undang Nomor 22

Tahun 2004 tentang Komisi Yudisial.

Undang-undang Nomor 4 Tahun 2004 tentang Kekuasaan Kehakiman.

Undang-undang Nomor 4 Tahun 2014 tentang Penetapan Peraturan Pemerintah Pengganti Undang-undang Nomor 1 Tahun 2013 tentang Perubahan Kedua atas undang-undang Nomor 24 Tahun 2003 tentang Mahkamah Konstitusi menjadi Undang-undang.

\section{Jurnal dan Internet}

Jurnal Konstitusi Vol. 1 No. 1 November, Mahkamah Konstitusi, Jakarta, 2008

Jurnal Konstitusi, Volume 10, Nomor 4. Desember, Kepaniteraan dan Sekretariat Jenderal MK, 2013, Jakarta.

Yohanes Usfunan, Pengawasan Hakim, dalam http://www.kompas.com/kompas-cetak /0703/15/opini/3369799.htm , (terakhir kali dikunjungi pada 21 Mei 2014 jam 13.20 WIB). 